\title{
Meningkatkan Hasil Belajar Siswa pada Pembelajaran FPB dan KPK Menggunakan Alat Peraga Dakon
}

\author{
Aldi Prasetyo', Yusuf Suryana², Geri Syahril Sidik ${ }^{3}$ \\ 1,3Universitas Perjuangan Tasikmalaya, ${ }^{2}$ Universitas Pendidikan Indonesia \\ aldi29690@gmail.com
}

\section{Article History}

accepted 2/11/2019

approved 23/11/2019

published 31/12/2019

\begin{abstract}
Abstract. The problem in this study is the low student learning outcomes in mathematics learning the subject of the Biggest Fellowship Factor (FPB) and the Smallest Multiple Multiplication (KPK) in Class V. This study aims to determine the increase in student learning outcomes by using dakon props on the subject of FPB and KPK in Class $V$ of SDN 1 Nagarasari. The method used in this study is the Classroom Action Research (CAR) method. The results showed that in the first cycle the average value of student learning outcomes was 72.73 with learning completeness $56.67 \%$. Cycle II average student learning outcomes 79.27 with learning completeness $83.33 \%$. An increase in the average score of student learning outcomes by 14.2 points. Based on the increase of each cycle, it can be concluded that the use of dakon props can improve student learning outcomes in FPB and KPK material in class $V$ of SDN 1 Nagarasari, Cipedes District, Tasikmalaya City Academic Year 2018/2019.
\end{abstract}

Keywords: Dakon Props, Learning Outcomes.

\begin{abstract}
Abstrak
Masalah dalam penelitian ini adalah rendahnya hasil belajar siswa pada pembelajaran matematika pokok bahasan Faktor Persekutuan Terbesar (FPB) dan Kelipatan Persekutuan Terkecil (KPK) di Kelas V. Penelitian ini bertujuan untuk mengetahui peningkatan hasil belajar siswa dengan menggunaan alat peraga dakon pada pokok bahasan FPB dan KPK di Kelas V SDN 1 Nagarasari. Metode yang digunakan dalam penelitian ini yaitu metode Penelitian Tindakan Kelas (PTK). Penelitian ini dilaksanakan dalam dua siklus. Setiap siklus peneliti memberikan soal pre test, kemudian diberikan tindakan menggunakan alat peraga dakon. Siswa diberikan soal post test, selanjutnya peneliti merefleksi kegiatan penelitian untuk perbaikan siklus selanjutnya. Hasil penelitian menunjukkan bahwa pada siklus I nilai rata-rata hasil belajar siswa 72,73 dengan ketuntasan belajar $56,67 \%$. Siklus II rata-rata hasil belajar siswa 79,27 dengan ketuntasan belajar $83,33 \%$. Peningkatan rata-rata skor hasil belajar siswa sebesar 14,2 poin. Berdasarkan peningkatan dari setiap siklus, dapat disimpulkan bahwa penggunaan alat peraga dakon dapat meningkatkan hasil belajar siswa pada materi FPB dan KPK di kelas V SDN 1 Nagarasari Kecamatan Cipedes Kota Tasikmalaya Tahun Ajaran 2018/2019.
\end{abstract}

Kata Kunci: Alat Peraga Dakon, Hasil Belajar

Social, Humanities, and Education Studies (SHEs): Conference Series https://jurnal.uns.ac.id/shes

p-ISSN 2620-9284

e-ISSN 2620-9292 


\section{PENDAHULUAN}

Standar Kompetensi dan Kompetensi Dasar matematika disusun sebagai landasan pembelajaran untuk mengembangkan mengembangkan kemampuan menggunakan matematika dalam pemecahan dan mengomunikasikan ide atau gagasan dengan menggunakan simbol, tabel, diagram, dan media lain. Menurut Ajun, Anita P (2013) "Pembelajaran matematika hendaknya dimulai dengan pengenalan masalah yang sesuai dengan situasi." Mengajukan masalah kontekstual, peserta didik secara bertahap dibimbing untuk menguasai konsep matematika. Salah satu kompetensi dasar yang termuat dalam mata pelajaran matematika kelas $\mathrm{V}$ yaitu menggunakan faktor prima untuk menentukan Faktor Persekutuan Terbesar (FPB) dan Kelipatan Persekutuan Terkecil (KPK). Maka dalam melaksanakan pembelajaran FPB dan KPK seharusnya guru menguasai materi yang akan diajarkan kepada siswa, menggunakan alat peraga yang dapat membuat siswa mengerti dan fokus terhadap materi yang akan dijelaskan dan menguasai kelas sehingga proses pembelajaran dapat berjalan lancar sesuai yang diharapkan.

Hasil evaluasi pembelajaran yang dilakukan oleh guru kelas, kemampuan siswa dalam pembelajaran matematika belum mencapai skor yang memuaskan dan masih di bawah standar ketuntasan minimal sekolah. Biasanya siswa kesulitan memahami maksud soal dan merubah bentuk soal kedalam kalimat matematika sehingga salah dalam menentujkan jawaban (Sidik, 2016; Sidik, 2019). Demikian yang terjadi di kelas V SDN 1 Nagarasari Kecamatan Cipedes Kota Tasikmalaya Tahun Ajaran 2018-2019, dari 30 siswa yang mengikuti ulangan mata pelajaran matematika pada pokok pembahasan Menentukan FPB dan KPK hanya 13 siswa yang mencapai tingkat penguasaan materi $75 \%$. Berdasarkan hasil pengamatan, faktor-faktor yang menyebabkan rendahnya hasil belajar siswa yaitu, materi Faktor Persekutuan Terbesar (FPB) dan Kelipatan Persekutuan Terkecil (KPK) hanya secara simbolik tanpa menggunakan alat peraga atau media pembelajaran. Restianingrum (2016) mengemukakan bahwa "Penggunaan media akan membantu memahami konsep, sesuai karakteristik pola pikir siswa Sekolah Dasar yang masih konkret." Cara pembelajaran yang disampaikan tidak menarik perhatian siswa dalam proses pembelajaran, sehingga ada beberapa siswa yang kurang bisa memahami penjelasan guru, dan mereka malu untuk bertanya pada guru tentang hal-hal yang belum dipahami. Suherman (2013) menyatakan bahwa "pembelajaran matematika dengan menggunakan alat peraga, maka siswa akan termotivasi dalam belajar sehingga hasil belajar siswa meningkat."

Berdasarkan hasil observasi di kelas $\mathrm{V}$ bahwa guru sudah melakukan banyak hal untuk memperbaiki hasil belajar siswa diantaranya; 1) memberikan remedial dengan pemberian soal berulang kepada siswa yang hasil belajarnya rendah. Hasibuan, $\mathrm{N}$. (2014) menyatakan bahwa "Pembelajaran remedial merupakan layanan pendidikan yang diberikan kepada peserta didik untuk memperbaiki prestasi belajarnya sehingga mencapai kriteria ketuntasan yang ditetapkan." Pemberian remedial tanpa dijelaskan kembali materi yang diajarkan, hanya memberikan kembali soal-soal yang dirasa sulit itu belum efektif. 2) pemberian soal-soal cerita tetapi tidak menggunakan alat peraga dalam pembelajaran, siswa hanya tahu saja tetapi belum mengerti dan paham materi FPB dan KPK. Menurut Afiyani, E (2012) "Penggunaan alat peraga dalam pemberian soal cerita pada pembelajaran matematika efektif meningkatkan hasil belajar siswa." Pemberian soal cerita saja tanpa menggunakan alat peraga belum efektif, sehingga hasil belajar siswa pada materi FPB dan KPK masih rendah.

Salah satu alternatif alat peraga yang efektif digunakan adalah penggunaan dakon dalam pembelajaran FPB dan KPK. Menurut Kurniati (2017) dan Shanti, F.D. (2016) "Dakon adalah suatu alat peraga inovasi baru yang digunakan sebagai media pembelajaran matematika." Sundayana (2015) kegunaan dakon yaitu "untuk 
menentukan faktor persekutuan terbesar (FPB) dan kelipatan persekutuan terkecil (KPK)." Dakon merupakan media pembelajaran yang dihasilkan dari penggabungan permainan tradisional dan pembelajaran matematika yang berguna untuk menentukan FPB dan KPK. Menurut Sulastri, dkk. (2015); Lesthary, D. dkk. (2017) "Penggunaan alat peraga dakon dapat meningkatkan hasil belajar siswa pada pembelajaran matematika." Dakon menggabungkan antara permainan tradisional dan pembelajaran matematika. Sehingga diharapkan selain mampu menjadi alat peraga pembelajaran matematika yang menyenangkan, dakon juga mampu melestarikan salah satu permainan tradisional dan diharapkan mampu meningkatkan hasil belajar dalam pembelajaran FPB dan KPK.

Berdasarkan latar belakang tersebut, peneliti tertarik melakukan penelitian pada pembelajaran Matematika untuk Meningkatkan Hasil Belajar Siswa Pada Pembelajaran FPB dan KPK Menggunakan Alat Peraga Dakon di kelas V SDN 1 Nagarasari Kecamatan Cipedes Kota Tasikmalaya. Tujuan penelitian ini, yaitu 1) untuk mendeskripsikan perencanaan pembelajaran dengan penggunaan alat peraga dakon untuk meningkatkan hasil belajar siswa pada pembelajaran FPB dan KPK di kelas V, 2) untuk mendeskripsikan proses pelaksanaan pembelajaran dengan penggunaan alat peraga dakon untuk meningkatkan hasil belajar siswa pada pembelajaran FPB dan KPK di kelas $V$, 3) untuk mendeskripsikan peningkatan hasil belajar siswa dengan penggunaan alat peraga Dakon pada pembelajaran FPB dan KPK di kelas V.

\section{METODE}

Metode yang digunakan dalam penelitian ini adalah metode Penelitian Tindakan Kelas (PTK). Peneliti melakukan penelitian tindakan kelas dengan tahapan sebagai berikut:

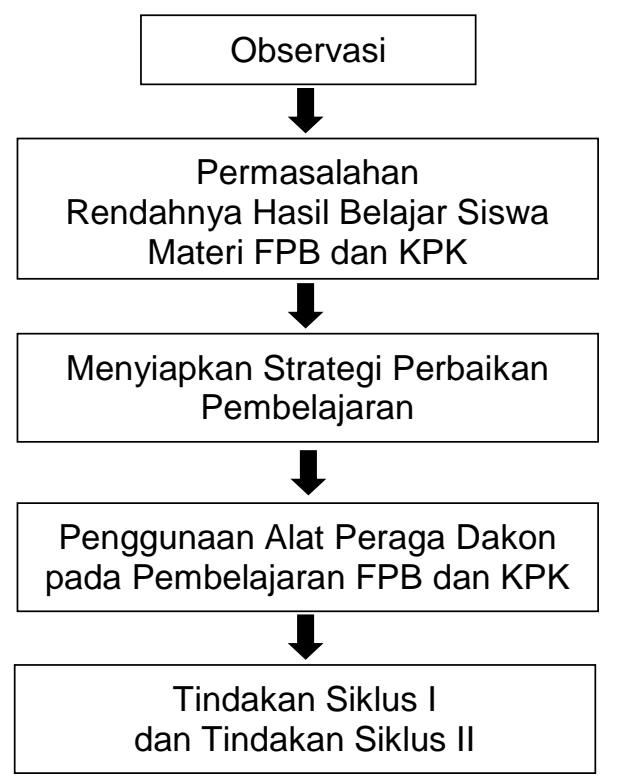

Gambar 1. Tahap Penelitian

Penelitian ini dilaksanakan di kelas V SDN 1 Nagarasari Kecamatan Cipedes Kota Tasikmalaya Tahun Pelajaran 2018/2019 pada 30 siswa. Peneliti menemukan permasalahan yaitu rendahnya hasil belajar siswa pada materi FPB dan KPK. Dikarenakan proses pembelajaran belum menggunakan alat peraga, peneliti meyiapkan strategi perbaikan pembelajaran dengan menggunakan alat peraga dakon pada pembelajaran FPB dan KPK. Peneliti memberikan soal pre test untuk mengetahui 
kemampuan awal siswa, pada materi FPB dan KPK sebelum pelaksanaan tindakan perbaikan pembelajaran dengan menggunakan alat peraga dakon.

Pada penelitian ini terdapat tiga teknik pengumpulan data untuk memperoleh data-data empiris yang dapat digunakan untuk mencapai tujuan penelitian yaitu, teknik observasi, tes dan dokumentasi. 1) Teknik observasi digunakan untuk mengumpulkan data aktivitas siswa dan peneliti selama proses pembelajaran dengan menggunakan lembar aktivas peneliti, lembar observasi aktivitas siswa dan penskoran kesesuaian atau ketepatan RPP. Lembar observasi terhadap peneliti menggunakan instrumen APKG (adaptasi dari pedoman FKIP Kampus Universitas Perjuangan Tasikmalaya) dengan memperhatikan aktivitas peneliti dalam pengelolaan pembelajaran menggunakan alat peraga dakon diisi oleh observer (guru kelas/teman sejawat) pada setiap kegiatan pembelajaran berlangsung; 2) Tes yang digunakan dalam teknik pengumpulan data ini adalah tes tertulis untuk mengukur hasil belajar siswa pada materi pembelajaran FPB dan KPK. Peneliti juga memberikan soal pre test sebelum diterapkannya alat peraga dakon untuk mengetahui pemahaman awal siswa, dan memberikan soal post test setelah diterapkan alat peraga dakon; 3) Teknik dokumentasi bentuk dari dokumentasi pada penelitian ini antara lain RPP, silabus, daftar skor siswa, daftar kehadiran siswa, serta foto pada saat kegiatan pembelajaran menggunakan alat peraga dakon.

Penelitian ini dilaksanakan dalam 2 siklus. Penelitian ini dimulai pada tanggal 29 April 2019 sampai dengan 13 Mei 2019. Peneliti menyiapkan instrumen penelitian diantaranya; RPP, LKS, Lembar soal post test, instrumen observasi, media pembelajaran yaitu alat peraga dakon, dan menyiapkan semua yang dibutuhkan dalam pelaksanaan tindakan. Pelaksanaan tindakan perbaikan pembelajaran sesuai RPP yang dibuat peneliti dengan menggunakan alat peraga dakon pada pembelajaran FPB dan KPK. Proses pelaksanaan pembelajaran diamati oleh observer dan dinilai dengan menggunakan lembar observasi. Peneliti mengumpulkan data sesuai instrumen yang direncanakan. Peneliti memberikan soal post test untuk mengukur peningkatan hasil belajar siswa pada pembelajaran FPB dan KPK dengan menggunakan alat peraga dakon. Peneliti merefleksi kegiatan penelitian untuk perbaikan siklus selanjutnya. Data yang diperoleh berupa hasil observasi dan hasil belajar siswa, kemudian diolah dan dianalisis menggunakan teknik penghitungan yang telah ditetapkan menurut para ahli. Data hasil analisis kemudian dipaparkan dalam bentuk tabel frekuensi dan grafik. Peneliti menarik kesimpulan berdasarkan kriteria keberhasilan yang ditetapkan. Peneliti melakukan verifikasi untuk melakukan tindakan perbaikan selanjutnya.

\section{Hasil Penelitian}

\section{HASIL DAN PEMBAHASAN}

1. Perencanaan Pembelajaran

Berikut adalah hasil observasi dalam pemenuhan aspek-aspek rencana pelaksanaan pembelajaran:

Tabel 1. Hasil Observasi RPP

\begin{tabular}{|c|c|c|}
\hline Siklus & Rata-Rata & Persentase (\%) \\
\hline I & 3,21 & $80,36 \%$ \\
\hline II & 3,82 & $95,53 \%$ \\
\hline
\end{tabular}

Berdasarkan tabel 1. Penilaian Rencana Pelaksanaan Pembelajaran pada materi FPB dan KPK menggunakan alat peraga dakon siklus I menunjukkan hasil yang "Baik". Hal ini didasarkan atas hasil observasi, masih ada indikator yang belum sesuai, yaitu indikator metode yang digunakan dalam pembelajaran belum 
4th National Seminar on Guidance and Counseling (SNBK 2019) and Workshop on

Pedagogical Theory and Practice (WTPP 2019)

SHEs: Conference Series 2 (2) (2019) 64 - 72

bervariasi dan belum berpusat pada siswa. Siklus II telah memenuhi kriteria keberhasilan dengan kategori yang diperoleh "Sangat Baik."

2. Pelaksanaan Pembelajaran berikut:

Hasil observasi pelaksanaan pembelajaran dirinci pada tabel 2. Sebagai

Tabel 2. Hasil Observasi Kinerja Guru

\begin{tabular}{|c|c|c|}
\hline Siklus & Rata-Rata & Persentase (\%) \\
\hline I & 3,28 & $82,14 \%$ \\
\hline II & 3,85 & $96,42 \%$ \\
\hline
\end{tabular}

Hasil observasi dalam proses pelaksanaan pembelajaran pada materi FPB dan KPK menggunakan alat peraga dakon siklus I dikatakan "Baik". indikator yang dirasa belum terpenuhi dengan baik, yaitu penyajian bahan pembelajaran masih belum berorientasi pada siswa secara menyeluruh. Pada siklus II telah terlaksana dengan baik, kategori "Sangat Baik."

Hasil pengamatan aktivitas siswa terinci pada tabel sebagai berikut:

Tabel 3. Hasil Observasi Aktivitas Siswa

\begin{tabular}{|c|c|c|}
\hline Siklus & Rata-Rata & Persentase (\%) \\
\hline I & 2,8 & $70 \%$ \\
\hline II & 3,6 & $90 \%$ \\
\hline
\end{tabular}

Hasil observasi aktivitas siswa dalam proses pembelajaran pada materi FPB dan KPK dengan menggunakan alat peraga dakon pada siklus I termasuk kategori "Cukup", karena siswa kurang menyimak penjelasan dari guru dan presentasi tiap kelompok. Siklus II hasil pengamatan aktivitas siswa termasuk pada kategori "Sangat Baik."

3. Hasil Belajar Siswa

Hasil belajar pada siswa dapat dilihat pada tabel 4 sebagai berikut:

Tabel 4. Perbandingan Antar Siklus

\begin{tabular}{|c|c|c|c|c|c|c|c|c|}
\hline \multirow[b]{2}{*}{$\frac{\frac{n}{2}}{\omega}$} & \multirow{2}{*}{$\begin{array}{l}\frac{\pi}{\infty} \\
\frac{-\infty}{\omega} \\
\frac{c}{\pi} \\
\frac{\pi}{5}\end{array}$} & \multirow{2}{*}{ 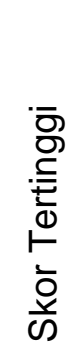 } & \multirow{2}{*}{$\begin{array}{l}\frac{c}{0} \\
\frac{0}{0} \\
\frac{d}{d} \\
\frac{0}{-} \\
\bar{d} \\
\frac{0}{\omega}\end{array}$} & \multirow{2}{*}{ 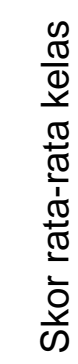 } & \multicolumn{2}{|c|}{ 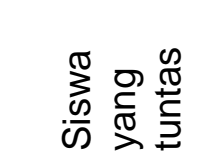 } & \multicolumn{2}{|c|}{ 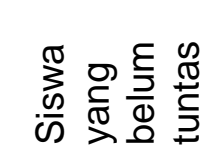 } \\
\hline & & & & & $\frac{\frac{c}{\sqrt{\sigma}}}{\frac{\varepsilon}{3}}$ & 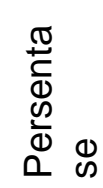 & $\frac{\frac{c}{\pi}}{\frac{\pi}{5}}$ & 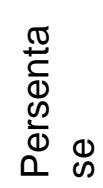 \\
\hline I & 30 & 90 & 44 & 72 & 17 & $57 \%$ & 13 & $43 \%$ \\
\hline II & 30 & 98 & 55 & 79 & 25 & $83 \%$ & 5 & $17 \%$ \\
\hline
\end{tabular}

Terlihat bahwa siklus I ke siklus II terjadi peningkatan rata-rata kelas dari 72 menjadi 79 dengan ketuntasan yang juga terjadi peningkatan sebesar $26 \%$ yaitu dari $57 \%$ menjadi $83 \%$. Persentase ketuntasan kelas $\mathrm{V}$ yang dicapai pada siklus 1 ke siklus 2 tersebut telah mencapai standar yang ditentukan di SDN 1 Nagarasari yaitu $75 \%$ siswa tuntas KKM, serta skor rata-rata kelas juga telah mencapai KKM yang telah ditentukan yaitu 73. Lebih jelasnya akan disajikan perbandingan jumlah siswa yang Tuntas dan Belum Tuntas siklus 1 dan siklus 2 dalam bentuk grafik berikut ini: 


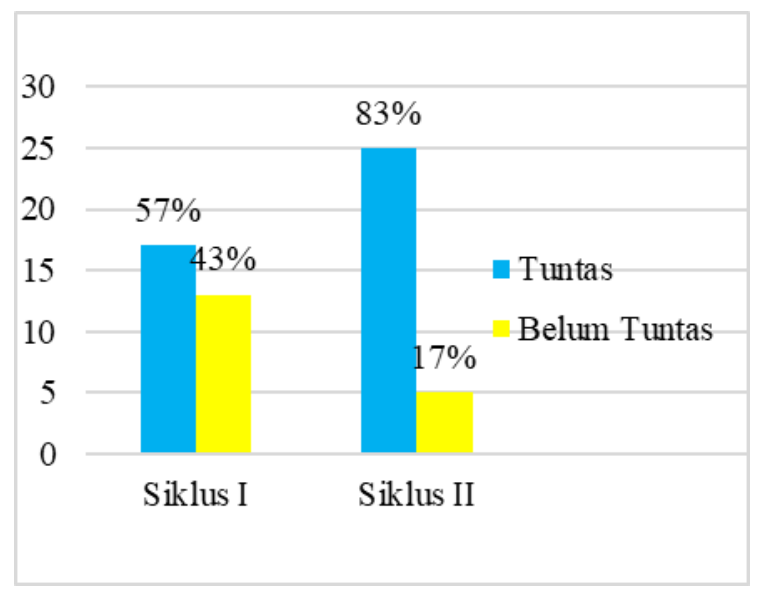

Grafik 2. Perbandingan Antar Siklus

\section{Pembahasan}

Peneliti melakukan pengamatan sebelum melaksanakan penelitian tindakan kelas, untuk menentukan tindakan yang tepat agar pembelajaran berlangsung lebih baik. Langkah awal yang dilakukan yaitu melakukan pengamatan dengan melihat proses pembelajaran di dalam kelas. Hasil pengamatan tersebut diketahui bahwa media pembelajaran yang digunakan kurang bervariasi dan hanya menggunakan media berupa papan tulis. Pengamatan juga dilakukan dengan melihat hasil ulangan materi FPB dan KPK bahwa sebagian besar 66,67\% (20 siswa) masuk dalam kategori belum tuntas dan 33,33\% (10 siswa) masuk dalam kategori tuntas, selain itu rata-rata kelas $(65,07)$ masih di bawah KKM yang telah ditentukan yaitu 73. Atas dasar data tersebut, maka dapat disimpulkan bahwa hasil belajar matematika siswa kelas V SDN 1 Nagarasari masih rendah sehingga perlu diadakannya upaya perbaikan untuk mengatasi permasalahan tersebut meliputi :

1. Perencanaan Pembelajaran

Peneliti membuat RPP sebelum melaksanakan penelitian, sesuai silabus mata pelajaran matematika dengan kompetensi dasar 1.2 menggunakan faktor prima untuk menentukan FPB dan KPK. Peneliti melaksanakan penelitian dengan 2 siklus, dimana setiap siklus dilengkapi dengan Rencana Pelaksanaan Pembelajaran (RPP), Lembar Kerja Siswa (LKS), Lembar Soal Pre Test dan Post Test, Lembar Observasi (Instrumen Penskoran). Penilaian RPP digunakan lembar observasi instrumen penilaian RPP. Berdasarkan hasil observasi Rencana Pelaksanaan Pembelajaran dapat disimpulkan bahwa terdapat peningkatan dalam merancang perencanaan pembelajaran pada materi FPB dan KPK menggunakan alat peraga dakon, pada siklus I dengan jumlah skor yang diperoleh yaitu 22,5 dan pesentase sebesar $80.36 \%$. Pada siklus II meningkat jumlah skor yang diperoleh menjadi 26,75 dengan persentase $95,53 \%$. Jadi pada penelitian ini, peneliti sudah mengalami peningkatan dalam merancang perencanaan pembelajaran dengan skor akhir persentasenya tidak kurang dari $75 \%$.

2. Pelaksanaan Pembelajaran

Proses kegiatan belajar mengajar merupakan hubungan interaksi antara siswa dan guru dalam situasi pembelajaran untuk mencapai tujuan pembelajaran. Pelaksanaan pembelajaran pada setiap siklus dilaksanakan sesuai perencanaan pembelajaran yang telah direncanakan sebelumnya. Pada penelitian ini, proses pelaksanaan pembelajaran dinilai dengan menggunakan instrumen penilaian kinerja guru. Melalui lembar observasi kinerja guru, dapat dilihat bagaimana peneliti melaksanakan pembelajaran dengan menggunakan alat peraga dakon pada setiap siklusnya mengalami peningkatan. Berdasarkan hasil observasi Siklus I, penilaian 
kinerja guru dapat dikatakan "Baik" dengan persentase yang didapat yaitu $82,14 \%$ dan rata-rata 3,28 . Pada siklus II mengalami peningkatan dengan kategori "Sangat Baik" dan persentase yang diperoleh yaitu $96,42 \%$ dengan rata-rata 3,85 . Pelaksanaan pembelajaran dengan alat peraga dakon, memberikan perubahan lebih baik dalam proses pembelajaran yaitu: siswa dapat termotivasi untuk belajar, aktif dalam pembelajaran, dapat bersikap baik dalam menyimak penjelasan guru dan kelompok lain sehingga berpengaruh terhadap pencapaian hasil belajarnya. Hal ini sesuai dengan pendapat Suherman (2013) "pembelajaran matematika dengan menggunakan alat peraga, maka proses belajar mengajar termotivasi." Maka dari itu, dengan menggunakan alat peraga dakon, motivasi siswa dan proses pembelajaran menjadi aktif, sehingga berpengaruh terhadap hasil belajar siswa.

Hasil observasi aktivitas siswa selama proses pembelajaran, berdasarkan hasil penelitian menunjukkan bahwa dengan menggunakan alat peraga dakon pada materi FPB dan KPK di setiap siklus aktivitas siswa mengalami peningkatan. Siklus I aktivitas siswa dikatakan "Cukup" dengan persentase $70 \%$ dan rata-rata yang diperoleh yaitu 2,8. Siklus II, aktivitas siswa mengalami peningkatan termasuk pada kategori "Sangat baik" dengan persentase 90\% dan rata-rata yang diperoleh yaitu 3,6. Penggunaan alat peraga dakon pada materi FPB dan KPK membuat siswa lebih aktif dalam proses pembelajaran, siswa termotivasi dan aktif dalam mengajukan pendapat, karena setiap indikator terutama indikator dalam menyimak penjelasan guru dan menyimak presentasi kelompok lain meningkat dari siklus I ke siklus.

3. Hasil Belajar Siswa

Hasil belajar dari kedua tindakan terjadi peningkatan yang signifikan dari kedua siklus. Berdasarkan hasil analisis, siklus 1 ke siklus 2 terjadi peningkatan rata-rata kelas dari 72 menjadi 79 dengan ketuntasan yang juga terjadi peningkatan sebesar $26 \%$ yaitu dari $57 \%$ menjadi $83 \%$. Presentase ketuntasan kelas V yang dicapai pada siklus 1 ke siklus 2 tersebut telah mencapai standar yang ditentukan di SDN 1 Nagarasari yaitu 75\% siswa tuntas KKM, serta skor rata-rata kelas juga telah mencapai KKM yang telah ditentukan yaitu 73. Persentase siswa yang tuntas pada siklus 1 diambil dari skor tes pada materi menentukan dua bilangan faktor prima FPB dan KPK menggunakan alat peraga dakon siswa yang tuntas adalah 57\% (17 siswa). Pada siklus 2, presentase siswa yang tuntas diambil dari tes siklus 2 pada materi menentukan tiga bilangan faktor prima KPK dan FPB menggunakan alat peraga dakon adalah $83 \%$ (25 siswa). Diagram di atas menunjukkan peningkatan jumlah siswa tuntas dari prasiklus, siklus 1 dan siklus 2. Kondisi tersebut juga diiringi dengan menurunya jumlah siswa yang Belum Tuntas mulai siklus I sebanyak 13 siswa, dan siklus II menjadi 5 siswa. Hasil tersebut telah memenuhi indikator kinerja pada penelitian ini yaitu $75 \%$ tuntas dengan KKM 73, sehingga pelaksanaan pembelajaran dihentikan pada siklus 2. Hal ini dikarekan sudah mencapai indikator kinerja yaitu rata-rata kelas secara klasikal telah mencapai KKM, jumlah siswa yang mencapai KKM telah mengalami peningkatan, dan $75 \%$ siswa telah mencapai KKM yang ditentukan. Menurut (Sobari,2017; dan Septiyana, 2017) bahwa penggunaan alat peraga dakon dapat meningkatkan hasil belajar matematika siswa." Berdasarkan hasil penelitian yang dilakukan oleh peneliti, relevan dengan penelitian yang dilakukan oleh peneliti tersebut. Berdasarkan hasil peneletian, dapat disimpulkan bahwa hasil belajar siswa pada materi FPB dan KPK menggunakan alat peraga dakon mengalami peningkatan di Kelas $V$ SDN 1 Nagarasari Kecamatan Cipedes Kota Tasikmalaya Tahun Ajaran 2018/2019. 


\section{SIMPULAN}

Berdasarkan hasil penelitian dan pembahasan yang telah diuraikan, peneliti dapat menarik kesimpulan bahwa pembelajaran matematika pada materi FPB dan KPK dengan menggunakan alat peraga dakon dapat meningkatkan hasil belajar siswa Kelas V SDN 1 Nagarasari Kecamatan Cipedes Kota Tasikmalaya Tahun Ajaran 2018/2019. Peningkatan hasil belajar siswa ditinjau dari:

1. Perencanaan pembelajaran pada materi FPB dan KPK menggunakan alat peraga dakon setiap siklus mengalami peningkatan. Perencanaan pembelajaran yang dibuat peneliti setelah diberikan tindakan dengan menggunakan alat peraga dakon termasuk kategori sangat baik. Seluruh indikator terpenuhi dengan baik, terutama indikator metode yang digunakan dalam pembelajaran bervariasi dan berpusat pada siswa, sehingga berpengaruh pada pelaksanaan pembelajaran dan peningkatan hasil belajar siswa.

2. Pelaksanaan pembelajaran matematika pada materi FPB dan KPK menggunakan alat peraga dakon di kelas V SDN 1 dapat berjalan dengan baik, sesuai dengan perencanaan pembelajaran yang telah ditentukan. Kategori yang diperoleh sangat baik. Hal ini dikarenakan seluruh indikator telah terpenuhi dengan baik.

3. Hasil analis menunjukkan bahwa, hasil pratindakan ketuntasan belajar siswa hanya mencapai persentase 33,33\% (10 siswa) dan yang belum tuntas KKM 66,67\% (20 siswa) dengan rata-rata 65,07 . Setelah dilakukannya tindakan penelitian dengan menggunakan alat peraga dakon hasil belajar siswa meningkat pada setiap siklus. Siklus I ketuntasan belajar siswa mencapai persentase sebesar 56,67\% (17 siswa) dan yang belum tuntas KKM 43,33\% (13 siswa) dengan rata-rata yang diperoleh 72,73. Siklus II mencapai persentase $83,33 \%$ (25 siswa) tuntas belajar, dan hanya $16,67 \%$ (5 siswa) belum tuntas KKM dengan rata-rata kelas yang diperoleh 79,27. Peningkatan rata-rata skor hasil belajar siswa sebesar 14,2 poin.

DAFTAR PUSTAKA

Afiyani, E. (2012). Upaya Meningkatkan Kemampuan Menyelesaikan Soal Cerita dalam Pembelajaran Matematika Materi Pecahan Sederhana dengan Menggunakan Alat Peraga pada Siswa Kelas IV MI Muhammadiyah Badakarya Kecamatan Punggelan Banjarnegara.

Ajun, Anita P. (2013). Development Of Long And Square Learning Device With A Realistic Mathematical Approach Based On Bruner Theory For Student Classy VII SMP Negeri 1 Palopo. Jurnal Daya Matematis, 1 (1):71.

Hasibuan, N. (2014). Mengoptimalkan Hasil Belajar Melalui Pembelajaran Remedial. Edukasia: Jurnal Penelitian Pendidikan Islam, 9 (2).

Kurniati, Suci, I. (2017). Penerapan Alat Peraga Dakon Matematika (Dakon) dalam Pembelajaran Matematika KPK dan FPB. [Online]. Tersedia: http://www.kompasiana.com/suciindahkurniati/59891e8288575a0acf6fa792/pener apan-alat-peraga-dakon-matematika-dakon-dalampembelajaranmatematika-kpkdan-fpb. Diakses pada 22 Februari 2019.

Lesthary, D. dkk. (2017). Peningkatan Hasil Belajar Siswa Pada Pembelajaran Matematika Menggunakan Media Dakon Bilangan di SD. Jurnal Pendidikan dan Pembelajaran, 3(11).

Restianingrum. (2016). Improving the Mathematics Achievment by Using Number Line Media on 4th Grade Students. Jurnal Pendidikan Guru Sekolah Dasar, 15 (5):2.

Septiana, Dwi. (2017). Penggunaan Alat Peraga Dakon Untuk Meningkatkan Hasil Belajar FPB Dan KPK Pada Siswa Kelas IV SDN Kalitengkek. (Skripsi Program Studi Pendidikan Matematika FKIP Universitas Muhammadiyah Purworejo). Purworejo. 
Shanti, F. D. (2016). Penerapan Metode Education Games Berbasis Alat Peraga Dakon Untuk Meningkatkan Hasil Belajar Matematika Peserta Didik Kelas Iv Sd Islam An-Nashr Kauman Tulungagung.

Sidik, G. S. (2016). Analisis proses berpikir dalam pemahaman matematis siswa sekolah dasar dengan pemberian scaffolding. JPsd (Jurnal Pendidikan Sekolah Dasar), 2(2), 192-204.

Sidik, G. S., \& Nugraha, F. (2019). Proses Berpikir pada Pemahaman Matematik Siswa Sekolah Dasar Terkait Materi Operasi Hitung Perkalian dan Pembagian Pecahan [The Process of Thinking in Mathematical Understanding of Primary School Students Regarding Counting Operation Materials Multiplicat. PEDAGOGIA: Jurnal Pendidikan, 8(1), 45-52.

Sobari, A. (2017). Pengaruh penggunaan alat peraga dakon terhadap hasil belajar matematika siswa.

Suherman, Erman. (2013). Strategi Pengajaran Matematika Kontemporer. Bandung: Universitas Pendidikan Indonesia.

Sulastri, dkk. (2015). Pemanfaatan Media Alat Peraga untuk Meningkatkan Hasil Belajar Peserta Didik Pada Mata Pelajaran PKn di Kelas IV SDN 1 Toili. http://download. portalgaruda.org/article. php?article=296235\&val=5150\&title=Pem anfaatan\%20Media\%20Alat\%20Peraga\%20Untuk\%20Meningkatkan\%20\%20 Ha sil\%20Belajar\%20Peserta\%20Didik\%20Pada\%20Mata\%20Pelajaran\%20PKn\%2 0\%20di\%20Kelas\%20IV\%20SDN\%201\%20Toili.Diambil pada 20 Mei 2019.

Sundayana, Rostina. (2015). Media dan Alat Peraga dalam Pembelajaran Matematika. Bandung: Afabeta. 